\title{
MODEL KEPENGAYOMAN SRI SULTAN HAMENGKU BUWONO $X$ SAAT PANDEMI MELALUI TUTURAN “TIDHA-TIDHA" DALAM SAPA ARUH
}

\author{
SRI SULTAN HAMENGKU BUWONO X'S LEADERSHIP MODEL DURING PANDEMIC \\ THROUGH THE DEFINITION OF “TIDHA-TIDHA" IN SAPA ARUH
}

Marcelinus Justian Priambodo

Program Studi Bahasa dan Sastra Indonesia

Fakultas Ilmu Budaya Universitas Gadjah Mada

justianmarcelinus@gmail.com

(Naskah diterima tangga 8 Juni 2021, direvisi terakhir tanggal 8 November 2021, dan disetujui tanggal 22 November 2021)

DOI: https:/ / doi.org/10.26499/wdprw.v49i2.847

\begin{abstract}
This research aims to describeconcept from 'tidha-tidha' and analyze the affect of the concept of 'tidha-tidha' made by Sri Sultan Hamengku Buwono X with the conceptual metaphor of the coronavirus in the society of Yogyakarta. Data in this research is internal because it is only based on the reading of Serat Kalatidha and the transcript of Sri Sultan Hamengku Buwono X's speech. This research method uses the theory ofconceptual errors in cognitive linguistic. Sri Sultan Hamengku Buwono X interprets 'tidha-tidha' as contemplation with ourselves, others, and God. This new disaster has made people aware of the importanceof health as a form of gratitude that must be attempted. The results reveal that perspective and frame affect the meaning of 'tidha-tidha' made by Sri Sultan Hamengku Buwono X. The creation of this meaning has three functions consisting representative, directive, and declaration to change the conceptual metaphor of society. In his role as governor, Sri Hamengku Buwono X must change the way og communication as the leadership model and at the same time to respond that new disaster. The leadership model can be seen from the directions and instructions in the speech that are easy to understand through the intentional conceptual errors.
\end{abstract}

Keywords: meaning; intentional conceptual errors; leadership model

\begin{abstract}
Abstrak
Penelitian ini bertujuan untuk mendeskripsikan makna 'tidha-tidha' dan menganalisis pengaruh makna 'tidha-tidha' ciptaan Sri Sultan Hamengku Buwono X dengan metafora konseptual pandemi corona masyarakat DIY. Data penelitian bersifat data internal karena hanya berdasarkan pembacaan Serat Kalatidha dan hasil transkrip pidato Sri Sultan Hamengku Buwono X. Metode penelitian ini menggunakan pendekatan deskriptif analisis yang menggunakan teori erata konseptual linguistik kognitif. Hasil penelitian menunjukkan bahwa perspektif dan frame dan memengaruhi pembentukan makna 'tidha-tidha' ciptaan Sri Sultan Hamengku Buwono X. Sri Sultan Hamengku Buwono X memaknai 'tidha-tidha' sebagai kontemplasi dengan diri sendiri, sesama, dan Sang Pencipta.Bencana baru ini menyadarkan manusia pentingnya kesehatan sebagai rasa syukur yang harus diusahakan. Penciptaan makna ini memiliki tiga fungsi yaitu representatif, direktif, dan deklarasi dalam upaya mengubah metafora konseptual masyarakat. Dalam perannya sebagai gubernur, Sri Sultan Hamengku Buwono X harus mengubah cara komunikasisebagai bentuk pengayoman sekaligus menyikapi keadaan baru
\end{abstract}


tersebut. Model pengayoman terlihat dari arahan dan petunjuk dalam pidato yang mudah dipahami melalui erata konseptual kesengajaan.

Kata-kata Kunci: makna; erata konseptual; model pengayoman

\section{Pendahuluan}

Kebudayaan berasal dari buddayah bahasa Sansekerta yang berarti 'budi' atau 'akal' (Koentjaraningrat, 2016: 181). Penjelasan arti yang berkaitan dengan akal karena budaya terbentuk saat manusia memenuhi kebutuhan jasmani maupun rohani. Ada tiga wujud kebudayaan yaitu ide-ide dan gagasan, aktivitas manusia yang terpola, dan benda buatan manusia. Ide-ide dan gagasan merupakan wujud ideal kebudayaan karena memberikan kekhasan budaya manusia dalam menciptakan gagasan (Hadi, 2011: 1516). Kehidupan manusia menjadi teratur karena ide dan gagasan dapat memajukan dan menata kehidupan masyarakat itu sendiri.

Pengetahuan dalam diri manusia dikembangkan melalui bahasa.Karena penalaran dilakukan dalam bahasa, maka analisa dari suatu penyimpulan tergantung daripada analisa pernyataan yang menjadi pangkal pikir dan kesimpulan (Hilal, 2019: 217). Saat manusia semakin menggunakan nalarnya, komunikasi yang didasarkan budaya dalam kehidupan diatur menurut kondisi, waktu, dan sebabnya.Salah satu hasil dari kehendak manusia dalam komunikasi berbudaya adalah sastra (Noor, 2019: 208). Penciptaan karya sastra dipengaruhi kondisi psikologis dan kondisi-kondisi yang memengaruhi sastrawan seperti kondisi sosial, politik, penerbitan, kebijakan pemerintah, dan yang lainnya.

Keberadaan pengaruh karya sastra semakin diakui apabila gagasan dan konsep ideal intersubjektif dalam karya itu tergambar atau terulang kembali setelah pembuatannya. Beberapa waktu terakhir dalam pemberitaan-pemberitaan cetak maupun online, Serat Kalatidha sering menjadi topik pembicaraan di kalangan masyarakat Daerah Istimewa Yogyakarta (DIY) karena relevansi serat itu dengan kemunculan pandemi corona di Indonesia. Hal ini dipengaruhi tindakan Sri Sultan yang mengangkat Serat Kalatidha dalam pidato pada sapa aruh tanggal 23 Maret 2020. Acara ini diselenggarakan Pemerintah Provinsi DIY sebagai respon terhadap pandemi corona yang mulai melanda Indonesia.

Sri Sultan Hamengku Buwono $X$ menciptakan makna 'tidha' baru saat berpidato dalam acara tersebut. Penciptaan erata konseptual kesengajaan akan terjadi pada peristiwa bermuatan kepentingan karena bertujuan mendapatkan tujuan komunikasi dari penyelewengan informasi yang diinginkan (Arimi, 2015: 63). Oleh karena itu, penciptaan erata konseptual kesengajaan 'tidha-tidha' pasti memiliki tujuan tertentu yang ingin dicapai.

Adanya peristiwa penciptaan erata konseptual kesengajaan itulah yang ingin diteliti lebih lanjut. Topik ini menjadi penting untuk dijadikan bahan penelitian karena belum ada penelitian lain yang mengangkat topik serupa. Dirumuskan dua masalah dalam penelitian yaitu apa saja konsep makna 'tidha-tidha' ciptaan Sri Sultan Hamengku Buwono X dan bagaimana relasi antara konsep 'tidha-tidha' dengan metafora konseptual pandemi corona masyarakat DIY. Tujuan penelitian ini adalah mampu mendeskripsikan makna baru 'tidha-tidha' dan menganalisis pengaruh makna baru 'tidha-tidha' dengan metafora konseptual pandemi corona masyarakat DIY. Manfaat dari penelitian adalah mengetahui relasi antara tuturan, model kepengayomannya Sri Sultan dan meningkatkan minat peneliti lain 
dalam menggunakan linguistik kognitif sebagai objek formal penelitian.

Kegiatan mengonseptualisasi sesuatu selalu terjadi dalam cara berpikir, berbicara, atau menulis suatu ide. Dalam linguistik kognitif, konsep dapat dicitrakan secara verbal sehingga membentuk konsep leksikal. Pengalaman manusia dalam konseptualisasimenghasilkan arketipe konseptual yang bisa dikonsepkan oleh manusia di alam ini, seperti sesuatu yang bergerak, diam, gambar, wujud fisik, bendahidup, benda mati, gerakan benda alam, denyut nadi, dan sebagainya.

Erata konseptual adalah kesalahan pengidentifikasian makna informasi sebuah konsep yang dilakukan karena ketidaksengajaan atau kesengajaan. Masing-masing erata konseptual ini memiliki motif tersendiri. Erata konseptual yang dilakukan karena ketidaksengajaan adalah kondisi kesadaran atas kealpaan informasi sehingga terpancing untuk mendefinisikan informasi sendiri. Dampak erata konseptual jenis ini adalah miskomunikasi. Erata konseptual kesengajaan adalah kondisi kesadaran dalam penyelewengan informasi atas satu konsep ke informasi lain yang mirip atau berbeda untuk mendapatkan tujuan komunikasi yang diinginkan. Jenis data konseptual ini disebut miskonsepsi atau conceptual abuse.

\section{Metode}

Penelitian ini menggunakan Serat Kalatidha karya Raden Ngabehi Ranggawarsita dan hasil transkrip pidato sapa aruh Sri Sultan Hamengku Buwono X dalam video Youtube milik Humas Jogja tanggal 23 Maret 2020. sebagai objek material. Teori erata konseptual dalam lingkup linguistik kognitif merupakan objek formal. Data bersifat data internal karena hanya berdasarkan pembacaan Serat Kalatidha dan hasil transkrip bahasa Indonesia pidato Sri Sultan Hamengku Buwono X. Kedua data ini dipandang representatif sebagai data primer. Sudah barang tentu, data sekunder tetap diperlukan sejauh data primer memerlukan data dukungan.

\section{Hasil dan Pembahasan}

Pengalaman manusia dalam mengonseptualisasi sesuatu menghasilkan arketipe konseptual. Setiap pengelompokan arketipe konseptual akan menghasilkan prototipe kategori yaitu anggota konsep yang utama, sentral, atau dominan pada konsep-konsep yang setipe. Pembahasan ini akan mendeskripsikan konsep 'tidha' dalam Serat Kalatidha, konsep 'tidha-tidha, relasi antara konsep ciptaan Sri Sultan dengan metafora konseptual masyarakat luas, dan model kepengayoman Sri Sultan dalam situasi pandemi.

\subsection{Makna 'Tidha' dalam Serat Kalatidha}

Serat Kalatidha merupakan syair yang ditulis pujangga Raden Ngabehi Ronggowarsito pada tahun 1860 dalam masa pemerintahan Pakubuwono VIII. Serat Kalatidha yang terdiri dari dua belas bait dan ditulis sesuai dengan aturan tembang Sinom. Isi Serat Kalatidha dipercaya sebagai piwulang untuk pembentukan karakter ideal masyarakat Jawa (Setiyadi, 2013: 298). Pengertian makna adalah unsur bahasa yang didasarkan referen luar bahasa.Makna 'tidha' dapat diketahui dengan menerjemahkan beberapa bait Serat Kalatidha kedalam bahasa Indonesia. Terjemahan tekstual ini berdasarkan hasil terjemahan naskah salinan di Perpustakaan Taman Siswa Yogyakarta yang ditulis oleh Susanto (1991: 32-35):
I. Mankya darajating praja
kawuryan wus sunya ruri
rurah pangrehing ukara
karana tanpa palupi
atilar silastuti
sarjana sujana kelu
kalulun kalatidha
tidhem tandhaning dumadi
ardayeng rat dening karoban rubeda 
Sekarang martabat negara

tampak sunyi sepi

rusak pengendalian peraturan karena

tiada teladan

orang pandai dan orang luhur budinya

pun ikut

terhanyut zaman penuh kekacauan,

kesulitan dan kutukan suramlah tandatanda ciptaan kekacauan di bumi

dibanjiri oleh kesulitan-kesulitan.

IV. Kasok karoban pawarta

babaratan ujar lamis

pinudya dadiya pangarsa

wekasan alah kawuri

yen pinikir sayekti

mundhak apa aneng ngayun

andheher kaluputan

siniraman banyu lali

lamun tuwuh dadi kekembanging beko

Tertuangi kabar angin

ucapan palsu dipuja

menjadi pemuka

akhirnya terbelakang

jikalau dipikir sungguh-sungguh

bertambah apa ada di depan

menyemai kekeliruan

disiram air berupa lupa diri

jikalau tumbuh akan menjadi

bunga-bunga bencana

V. Ujaring Panitisastra

awawarah asung peling

ing jaman keneng musibat

wong ambek jatmika kontit

mengkono yen niteni

pedah apa amituhu

pawarta lalawora

mundhak angraranta ati

angur baya ngiketa cariteng kuna

\section{Kata Panitisastra}

yang memberi pelajaran dan

peringatan di tengah zaman

yang sedang diliputi oleh kutukan

orang berbudi baik justru tertinggal

demikian jika orang memperhatikan apa gunanya mempercayai

berita-berita yang tidak karuan

mengakibatkan kepiluan hati

lebih baik mengarang cerita kuna

VII. Amenangi jaman edan

ewuh-aya ing pambudi

milu edan nora tahan

yen tan milu anglakoni

boya kaduman melik

kaliren wekasanipun

dilalah karsa Allah

begja-begjane kang lali

luwih begja kang eling lawan waspada

Mengalami zaman gila

serba sulit dan bimbang bersikap

namun jika tidak turut melakukan

tidak akan memperoleh bagian

kelaparanlah akhirnya

telah menjadi kehendak Allah

seberuntungnya orang lupa

lebih untung yang masih memiliki

kesadaran dan kewaspadaan

X. Sakadare linakonan

mung tumindak mara ati

angger tan dadi prakara

karana wirayat muni

ikhtiyar iku yekti

pamilihing reh rahayu

sinambi budidaya

kanthi awas lawan eling

kang kaesthi antuka parmaning Suksma

Sekemampuannya dijalani

hanya berbuat hal-hal yang

menarik hati tidak menimbulkan

persoalankarena kisah yang memberikan

teladan mengatakan

berupaya itu sungguh

merupakan pilihan sikap menuju

keselamatan sambil berupaya

dengan waspada dan sadar

ingat yang diharapkan agar

memperoleh anugerah dari Tuhan 
Berdasarkan data di atas, dapat ditemukan beberapa makna 'tidha', di antaranya sebagai berikut.

a. Pada bait pertama baris ketujuh dan baris kedelapan, 'tidha' dimaknai sebagai 'kekacauan, kesulitan dan kutukan yang melanda suatu negara karena sikap buruk pejabat negara tersebut'.

b. Pada bait keempat, 'tidha' dimaknai sebagai 'bentuk-bentuk perilaku buruk berupa kebiasaan menyebarkan informasi palsu, lupa diri, dan sering melakukan kekeliruan'.

c. Pada bait kelima, 'tidha' dimaknai sebagai 'waktu untuk menulis cerita kuno dan berdoa kepada Panitisastra'.

d. Pada bait ketujuh, 'tidha' dimaknai sebagai 'zaman gila, serba sulit dan bimbang dalam bersikap'.

e. Pada bait kesepuluh, 'tudha' dimaknai sebagai 'situasi yang harus diwaspadai'

Makna 'tidha' pada Serat Kalatidha merupakan situasi buruk dalam suatu negara yang disebabkan perilaku buruk pejabat negara tersebut. Penggambaran ini terdapat pada bait pertama yang menggambarkan situasi yang terjadi tidak dapat diselesaikan hanya dengan akhlak baik para pejabat negara. Situasi buruk diwujudkan dalam bentuk kekacauan, kesulitan, kutukan, gila dan serba sulit. Wujud perilaku buruk pejabat negara adalah kebiasaan menyebarkan informasi palsu, lupa diri, dan sering melakukan kekeliruan.

\subsection{Makna 'Tidha-Tidha'Ciptaan Sri Sultan Hamengku Buwono X}

Pada tanggal 23 Maret 2020 dilaksanakan acara sapa aruh sebagai respon pemerintah provinsi terhadap pandemi corona yang mulai melanda DIY. Himbauan yang disampaikan berupa pidato. Dalam pidato tersebut, Sri Sultan mengangkat Serat
Kalatidha sebagai bahan pidato yang menjadi topik pembicaraan di kalangan masyarakat sampai saat ini.

Sri Sultan menciptakan makna baru 'tidha' dalam pidatonya untuk mencapai tujuan tertentu. Penciptaan makna baru 'tidha-tidha' dinamai erata konseptual kesengajaan karena dilakukan secara sadar dan menimbulkan miskonsepsi. Menurut Arimi (2015: 62), erata konseptual kesengajaan adalah kondisi kesadaran dalam penyelewengan informasi atas satu konsep ke informasi lain yang mirip atau berbeda untuk mendapatkan tujuan komunikasi yang diinginkan. Oleh karena itu, untuk mengetahui tujuan penciptaan makna baru ini maka disajikan transkrip bahasa Indonesia dan bahasa Jawa pidato Sri Sultan dari kanal Youtube Humas Jogja (2020).

Assalammualaikum wr. Wb.

Semoga kedamaian, keberkahan dan rahmat Tuhan Yang Maha Esa senantiasa menyertai kita semua.

Para warga Yogyakarta, juga anak-anakku yang sedang belajar di rumah, saudarasaudaraku semuanya.

Saya, Hamengku Buwono, pada hari-hari ini yang sarat akan ketidakpastian, yang digambarkan oleh Pujangga Wekasan, Ronggowarsito, dalam Serat Kalatidha, suasana tidha-tidha yang sulit diramal, penuh rasa was-was, saya mohon agar para warga agar bersama-sama memanjatkan doa ke hadirat Allah Subhanahu Wa Ta'ala, Tuhan Yang Maha Esa, agar kita diberi petunjuk di jalan lurus-Nya, kembali pada ketentraman lahir dan batin.

Di masa tanggap darurat bencana virus corona ini, kita harus menghadapinya dengan sikap sabar, tawakal, tulus, ikhlas, pasrah lahir batin disertai ikhtiar yang berkelanjutan. Sama seperti juga bagi saya, yang berkewajiban menjadi pamong praja beserta pemomong rakyat Yogyakarta, harus 
berpegang teguh pada ajaran Jawa: 'wong sabar rejekine jembar, ngalah urip luwih berkah'.

Suasana dualistis ini ibarat mata uang logam, dibalik bahaya ada peluang. Bagaikan pedang bermata dua, bisa untuk membunuh musibah atau untuk bertahan hidup. Islam mengajarkan, di balik cobaan hari ini selalu ada berkah yang datang kemudian. Kemudahan memang tampak enak dan bisa membuat orang terlena. Di mana seorang pengemudi mobil mengantuk? Bukan di jalan sulit dan sempit, tetapi di jalan raya yang mulus. Pepatah Jawa mengatakan: 'kesandung ing roto, kebentus ing tawang'.

Saudara-saudara warga Yogya yang saya cintai,

Berbeda dengan bencana gempa tahun 2006 yang kasat mata. Sekarang ini, virus corona itu jika memasuki badan tidak bisa kita rasakan dan menyerangnya pun tak terduga-duga. Menghadapi hal itu, kita selayaknya bisa menjaga kesehatan, laku prihatin dan juga wajib menjalankan aturan baku dari sumber resmi yang terpercaya. Saya yakin karena rakyat Yogyakarta memiliki kadar literasi yang tinggi, tentu bisa membedakan mana yang berita hoaks serta mana-mana yang benar-benar nalar. Pepatah Jawa kembali mengatakan: 'Gusti paring dalan kanggo uwong sing gelem ndalan'.

Karena itu, strategi mitigasi bencana nonalam ini, Daerah Istimewa Yogyakarta belum menerapkan lockdown melainkan calm down untuk menenangkan batin dan menguatkan kepercayaan diri agar eling lan waspada. Eling atas Sang Maha Pencipta dengan laku spiritual lampahratri, zikir malam, mohon pengampunan dan pengayoman-Nya.

Waspada, melalui kebijakan slow down, sedapat mungkin memperlambat merebaknya pandemi penyakit corona, dengan cara reresik diri dan lingkungannya sendirisendiri. Kalau merasa tidak sehat harus memiliki kesadaran dan menerima kalau wajib mengisolasi diri pribadi selama empat belas hari sama dengan masa inkubasi penyakitnya. Jaga diri, jaga keluarga, jaga persaudaraan, jaga masyarakat, dengan memberi jarak aman dan sedapat mungkin menghindari keramaian jika memang tidak mendesak betul. Bisa jadi kita merasa sehat tapi sesungguhnya tidak ada seorangpun yang bisa memastikan bahwa kita benarbenar sehat. Malah bisa jadi kita yang membawa bibit penyakit. Karena itu, saya mengingatkan pada pepatah Jawa lagi: 'datan serik lamun ketaman, datan susah lamun kelangan'.

Pesan saya singkat, waspadalah dan berhatihatilah, saudara-saudaraku! Doaku buat seluruh warga, sehat, sehat, sehat! Semoga Gusti Allah berkenan meridhai-Nya. Amin. Terima kasih.

Wassalamualaikum wr. wb.

Assalammualaikum wr. wb.

Mugi Gusti Allah tansah paring berkah tumraping kita sadaya,

Para warga Ngayogyakarta, uga anak-anakku kang lagisinau ing omah,

para sedulur kabeh wae,

Ingsun, Hamengku Buwono, ing dina kang kebak was-was lan tidha-tidha iki, nyuwun para warga sami ndedonga konjuk ing ngarsaning Gusti Allah, mugi kita saged enggal kaparingan pepadhang. Ing tanggap darurat awit saka sumebaring virus corona iki, kudu diadhepi kanthi sabar-tawakal, tulus-ikhlas, pasrah lahirbatin, lan kairing ikhtiyar kang tanpa kendhat. Semono uga, kita, kang kajibah ngesuhi para kawula. "Wong sabar rejekine jembar, Ngalah urip luwih berkah".

Beda karo prastawa lindu gedhe taun 2006 kang kasat-mata. Saiki, kang aran virus corona iku yen lumebu ing badan kita ora bisa karasa lan tekane uga ora kanyana-nyana. Kita kabeh kudu bisa njaga sehat, laku prihatin, lan uga wajib ngecakake aturan baku saka sumber resmi pamarentah kang wis diumumke ing masarakat. 
"Gusti paring dalan kanggo sapa wae gelem ndalan".

Mula pamundhutku, sing padha eling lan waspada. Eling marang Kang Gawe Agesang kanthi "lampah" ratri, zikir wengi, nyuwun pangaksami lan pangayomane Gusti. Waspada kanthi reresik diri lan lingkungane dewe-dewe. Nek krasa kurang sehat kudu ngerti lan narima yen wajib "mengisolasi diri" pribadi sajrone 14 dina. Jaga pribadi. Jaga keluwarga. Jaga paseduluran. Jaga masarakat. Kanthi jaga, rada ngadohi kumpul-kumpul bebarengan yen pancen ora wigati tenan. Bisa uga kita rumangsa sehat, ning ora ana kang bisa mesthekake yen kita bener sehat. Malah bisa uga nggawa bibit lelara. "Datan serik lamun ketaman, datan susah lamun kelangan". Pamundhutku mung saklimah: "Sing ngati-ati!"

Mung kita bisa atur pangajab nyuwun kalis ing bebaya lan tulak-sarik, lan uga bisaa tinebihna saka memala kang luwih gede sanggane tumraping kita manungsa. Pamujiku: "Sehat, sehat, sehat!".

Mugi Gusti Allah ngijabahi. Rahayu kang pinanggih. Aamiin. Nuwun.

Wassalamualaikum wr. wb.

Penggunaan dua bahasa ini tidak terlepas kondisi situasi kontak kedua bahasa di DIY saat ini (Suharyo, 2018: 253-254). Keadaan kontak bahasa di DIY terbagi menjadi tiga kelompok yaitu masyarakat dengan penguasaan bahasa Indonesia lebih fasih dibandingkan bahasa Jawa, masyarakat dengan penguasaan bahasa Jawa lebih fasih dibandingkan bahasa Indonesia, dan masyarakat yang penguasaan bahasa Jawa dan bahasa Indonesia seimbang (Munandar, 2013: 95). Oleh karena itu, penggunaan dua bahasa berbeda dalam berpidato dimaksudkan agar isi pidato dapat dimengerti dan dijalankan oleh seluruh kalangan masyarakat di DIY. Berdasarkan data di atas, terdapat beberapa makna baru 'tidha-tidha' yang diciptakan oleh Sri Sultan Hamengku Buwono X di antaranya sebagai berikut.

a. 'Tidha-tidha' dimaknai sebagai 'waktu untuk berpasrah diri ke hadirat Tuhan'

b. 'Tidha-tidha' dimaknai sebagai 'situasi laku prihatindengan menjaga kesehat$\mathrm{an}^{\prime}$

c. 'Tidha-tidha' dimaknai sebagai 'waktu untuk saling menjaga satu sama lain'

Penciptaan makna baru 'tidha-tidha' dipengaruhi perspektif dan frame yang dimiliki Sri Sultan. Perspektif adalah cara pandang suatu peristiwa dengan pengutamaan peserta (Arimi, 2015: 47). Sebagai penutur, perspektif yang digunakan Sri Sultan Hamengku Buwono $X$ adalah pamong praja dan pemomong masyarakat DIY. Frame adalah latar belakang pengetahuan dalam setiap satuan kebahasaan (Arimi, 2015: 65). Tiga makna baru yang diciptakan oleh Sri Sultan didasari frame keadaan dan frame harapan. Frame keadaan ditunjukkan dalam tuturan bahwa 'tidha-tidha' penuh ketidakpastian sedangkan frame harapan ditunjukkan melalui pengandaian 'tidha-tidha'sebagai dua sisi mata uang logam.

\subsection{Relasi Konsep 'Tidha-Tidha' dengan Metafora Konseptual Pandemi Corona Masyarakat DIY}

Munculnya pandemi corona yang tidak terprediksi seolah menambah daftar peristiwa bencana yang melanda DIY. Kondisi ini tentunya akan menimbulkan kepanikan karena belum ditemukannya solusi yang tepat untuk mencegah penyebaran dan penularan virus. Belum ditemukannya solusi yang tepat akan mendorong masyarakat menggunakan cara-cara irasional (Maharani, 2012: 96). Kecenderungan ini terbentuk karena pola pikir mistikisme dan pengetahuan lama (social stock of knowledge) yang masih melekat (Hatma \& Jaya, 2012: 128). Adanya himbauan dari pemimpin tertinggi 
di Yogyakarta merupakan salah satu cara untuk merubah dan menghilangkan pola pemikiran ini.

Penciptaan konsep baru 'Tidha-Tidha' oleh Sri Sultan Hamengku Buwono X memiliki tiga fungsi yaitu representatif, direktif, dan deklarasi. Pertama, representatif diwujudkan dalam pernyataan pidatonya yang menyam-paikan bahwa pandemi corona merupakan waktu berpasrah diri ke hadirat Tuhan. Kedua, direktif diwujudkan dalam pernyataan pidatonya yang meminta masyarakat DIY untuk menjaga kesehatan. Ketiga, deklarasi diwujudkan dalam pernyataan pidatonya yang mengumumkan bahwa pandemi corona adalah waktu saling menjaga satu sama lain.

Ketiga fungsi digunakan untuk memengaruhi metafora konseptual tentang pandemi corona yang ada dalam pikiran masyarakat DIY. Metafora konseptual adalah pemetaan konsep ekspresi kebahasaan dengan ekspresi kebahasaan lain (Nirmala, 2014: 6). Pemetaan ini menekankan bahwa suatu konsep dipahami sebagai konsep lain. Hal ini sama dengan pemahaman masyarakat bahwa 'pandemi corona adalah kesialan', 'PHK adalah imbas corona', serta 'pageblukgawe miskin'. Metafora konseptual ini merupakan implikasi pandemi yang memengaruhi fisik dan mental masyarakat (Nasrullah \& Sulaiman, 2021: 210). Hal ini berusaha diubah oleh Sri Sultan dengan menjelaskan pandemi secara empiris. Proses rasionalisasi terlihat dari penggunaan perumpaan Jawa yang berkaitan dengan kondisi saat ini dengan tidak menghilangkan penjelasan empiris di dalamnya. Tindakan Sri Sultan ini menan-dakan bahwa dirinya tidak berusaha merintangi proses rasionalisasi tersebut (Hatma \& Jaya, 2012: 139-140). Selain itu, penggunaan perumpaan juga dimaksudkan agar masyara-kat semakin memahami himbauan tersebut (Nirmala, 2016: 301-302).
Himbauan Sri Sultan dilatarbelakangi faktor sosial dan budaya. Pertama, bahasa menjadi telah menjadi identitas sosial dalam masyarakat karena adanya stratifikasi sosial (Sofyan, 2014: 76). Salah satu pembentuk stratifikasi sosial adalah interaksi sosial. Dasar untuk menggolongkan dalam lapisan sosial adalah kekayaan, kedudukan, dan ilmu pengetahuan (Ulfa, 2012: 40). Stratifikasi sosial ditentukankedudukandan peranan. Sebagai pemimpin wilayah DIY, Sri Sultan memiliki kedudukan dan peranan tertinggi dalam tatanan masyarakat. Posisi tertinggi ini tercermin dari gaya hidup sesuai dengan strata sosialnya (Kistanto, 2016: 106-107). Hal ini menyebabkan terjadinya penghormatan dan kepatuhan sebagai konsekuensi stratifikasi sosial.

Kedua, hubungan sosial antara bawahan kepada raja memiliki etika yang khas. Masyarakat DIY harus menjalankan perintah atau arahan Sultan sebagai wujud kebudayaan (Raditya, 2016: 9). Implementasi dari wujud pertama kebudayaan adalah adanya sistem norma dan aturan (Arditama, 2013: 87-88). Norma adalah aturan yang harus dipatuhi. Aturan untuk menghormati dan mematuhi arahan Sri Sultan digunakan untuk menata kehidupan masyarakat DIY. Norma tidak hanya digunakan sebagai tolak ukur dalam menilai perbuatan seseorang tetapi juga sebagai panduan berbuat dan bertingkah laku (Kirom, 2016: 107). Apabila melanggar norma maka dapat diberlakukan sanksi bagi pelanggar norma.

\subsection{Model Pengayoman Sri Sultan sebagai Gubernur DIY}

Keraton Yogyakarta memiliki pandangan Jawa bahwa raja adalah bagian tak terpisahkan dari pandangan hidup kosmikreligius-magis Jawa dan alam semesta (Dewi, 2017: 69). Dasar dari pandangan ini berada di semua aspek kehidupan. Pandangan dunia ini berakar pada kepercayaan kesinam- 
bungan hubungan antara alam semesta dan manusia (Siswanto, 2010). Konsep raja dan kekuasaan di Keraton Yogyakarta pada dasarnya tercermin dalam gelar raja: Sampeyan Dalem Ingkang Sinuwun Kangjeng Sultan Hamengku Buwono Senapati ing Ngalaga, Ngabdurrahman Sayidin Panatagama Khalifatullah. Gelar tersebut merupakan bentuksimbolik kerangka konsep-tual raja, kerajaan dan ketuhanan (Tolo, 2013: 272).

Gelar raja di Keraton Yogyakarta menjelaskan bahwa raja memiliki dua kekuasaan yaitu duniawi dan ilahi (Wardani, 2012: 59). Tugas adat utama Raja Jogja adalahmenjaga ketertiban, dan ketentraman negara serta memelihara perdamaian dan kemakmuran negara dan rakyatnya. Sejalan dengan hal tersebut, Sri Sultan yang juga menjadi Gubernur DIY menggunakan pendekatan sosial budaya dalam mengatasi pandemi. Hal ini juga dilatarbelakangi kondisi masyarakat yang masih memegang nilai-nilai luhur budaya.

Kepemimpinan terlihat dari sikap tegas dalam penentuan kebijakan untuk mencegah meluasnya pandemi di DIY. Hal ini dapat dilihat dengan dilakukannya sapa aruh sebagai bentuk hadirnya sosok pemimpin sehingga memberikan rasa damai dan tentram kepada masyarakat. Model kepengayoman Sri Sultan terlihat dalam pidatonya yang memberi arahan dan petunjuk melalui erata konseptual kesengajaan 'tidha-tidha' agar lebih mudah dipahami oleh masyarakat.

\section{Simpulan}

Penciptaan erata konseptual kesengajaan terhadap makna 'tidha-tidha' terjadi saat acara sapa aruh yang diselenggarakan pada 23 Maret 2020. Penciptaan makna 'tidha-tidha' yang baru yaitu 'waktu untuk mendekatkan diri kepada Tuhan agar tercipta ketentraman lahir dan batin antara diri sendiri dan lingkungan sekitar'. Hal ini berbeda dengan makna 'tidha' dalam Serat Kalatidha yang ditulis pujangga Raden Ngabehi Ronggowarsito tahun 1860 pada masa pemerintahan Pakubuwono VIII. Penciptaan erata konseptual kesengajaan akan terjadi pada peristiwa bermuatan kepentingan karena bertujuan mendapatkan tujuan komunikasi dari penyelewengan informasi yang diinginkan.

Penciptaan konsep baru 'tidha-tidha' oleh Sri Sultan Hamengku Buwono X memiliki tiga fungsi yaitu representatif, direktif, dan deklarasi. Konsep baru 'tidha-tidha' berhasil mengubah metafora konseptual masyarakat tentang pandemi. Hal ini dipengaruhi faktor sosial dan budaya. Pertama, bahasa menjadi telah menjadi identitas sosial dalam masyarakat karena adanya stratifikasi sosial. Sebagai pemimpin wilayah DIY, Sri Sultan memiliki kedudukan dan peranan tertinggi dalam tatanan masyarakat. Hal ini menyebabkan terjadinya penghormatan dan kepatuhan sebagai konsekuensi stratifikasi sosial. Kedua, hubungan sosial antara bawahan kepada raja harus menjalankan perintah atau arahan sebagai wujud kebudayaan. Hal ini digunakan sebagai panduan berbuat dan bertingkah laku.

Sebagai raja yang mewarisi tahta Keraton Yogyakarta, masyarakat DIY merasakan ada-nya perlindungan dan pengayoman dari Sri Sultan Hamengku Buwono X selama masa pandemi. Diadakannya sapa aruh sebagai bentuk hadirnya sosok pemimpin sehingga memberikan rasa damai dan tentram kepada masyarakat. Pola kepengayoman Sri Sultan terlihat dalam pidatonya yang memberi arahan dan petunjuk melalui makna baru 'tidha-tidha' agar lebih mudah dipahami oleh masyarakat.

\section{Daftar Pustaka}

Arditama, Erisandi. 2013. "Mereformasi Birokrasi dari Perspektif Sosio-Kultural: Inspirasi dari Kota Yogyakarta". Jurnal Sosial Politik, 17(1), 85-100. 
Arimi, Sailal. 2015. Linguistik Kognitif: Sebuah Pengantar. A.Com Press.

Dewi, Kurniawati Hastuti. 2017. “Pengangkatan Putri Mahkota Dan Indikasi Pergeseran Konsep Kuasa Jawa: Analisis Pendahuluan". Jurnal Masyarakat dan Budaya, 19(1), 59-76. https:// doi.org/10.14203/jmb.v19i1.3 98

Hadi, Sumasno. 2011. "Pemikiran Sutan Takdir Alisyahbana Tentang Nilai, Manusia, dan Kebudayaan". Jurnal Filsafat, 21(1), 1-19.

Hatma, Pajar danIndra Jaya. 2012. “Dinamika Pola Pikir Orang Jawa". Humaniora, Vol. 24, No. 2 Juni 2012: 133-140, 24(2), 133140. https://jurnal.ugm.ac.id/jurnalhumaniora/article/view/1056/885

Hilal, Muhammad. 2019. "Filsafat Bahasa Biasa Gilbert Ryle dan Relevansinya dengan Konsep Pendidikan Karakter di Indonesia". Jurnal Filsafat, 29(2), 206-227. https:/ / doi.org/10.22146/jf.44313

Humas Jogja. 2020. "Sapa Aruh Sri Sultan Hamengku Buwono X: "Cobaning Gusti Allah Awujud Virus Corona"". Video Youtube. 23 Maret 2020. https:/ / www.youtube.com/watch?v=I CkE5wjbj-o\&ab_channel=HumasJogja

Kirom, Syahrul. 2016. "Filsafat Ilmu Dan Arah Pengembangan Pancasila: Relevansinya Dalam Mengatasi Persoalan Kebangsaan". Jurnal Filsafat, 21(2), 99-117. https://doi.org/10.22146/jf.3111

Kistanto, Nurdien Harry. 2016. "Gaya Hidup Masyarakat Pascamoderen". Sabda, 11(4), 98-112.
Koentjaraningrat. 2016. Pengantar Ilmu Antropologi. Rhineka Cipta.

Maharani, Septiana Dwiputri. 2012. "Pandangan Gabriel Marcel Tentang Manusia Dalam Konteks Peristiwa Bencana Alam". Jurnal Filsafat, 22(2):91106. https:/ / doi.org/10.22146/jf.12989

Munandar, Aris. 2013. "Pemakaian Bahasa Jawa dalam Situasi Kontak Bahasa di Daerah Istimewa Yogyakarta". Humaniora, 25(1), 92-102. https://jurnal.ugm.ac.id/jurnalhumaniora/article/view/1819

Nasrullah, dan Lalu Sulaiman. 2021. "Analisis Pengaruh COVID-19 Terhadap Kesehatan Mental Masyarakat di Indonesia". Jurnal Media Kesehatan Masyarakat Indonesia, 20(3), 206-211. https:// doi.org/10.24198/focus.v3i1.2 8123

Nirmala, Deli. 2014. "Proses Kognitif dalam Ungkapan". Parole, 4(1), 1-13.

Words in Local Newspapers in Central Java As a Language Maintenance Model". Jurnal Humaniora, 27(3), 293304.

https:// doi.org/10.22146/jh.v27i3.105 89

Noor, Redyanto. 2019. "Fungsi SosialKultural Sastra: Memajukan Kebudayaan dan Mengembangkan Peradaban". Nusa: Jurnal Ilmu Bahasa dan Sastra, 14(2), 206. https:// doi.org/10.14710/nusa.14.2.2 06-216

Raditya, Michael HB. 2016. "Kontestasi Kekuasaan dan Keteladanan Semu di 
Indonesia". Jurnal Ilmu Sosial dan Ilmu Politik, 19(1), 1-15. https:// doi.org/10.22146/jsp.10853

Setiyadi, Dwi Bambang Putut.2013. "Discourse analysis of Serat Kalatidha: Javanese cognition system and local wisdom". Asian Journal of Social Sciences $\mathcal{E}$ Humanities, 2(4), 292-300.

Siswanto, Dwi. 2010. "Pengaruh Pandangan Hidup Masyarakat Jawa Terhadap Model Kepemimpinan". Jurnal Filsafat, 20(3), 198-214.

Sofyan, Nur.2014. "Bahasa Sebagai Simbolisasi Mempertahankan Kekuasaan". INTERAKSI: Jurnal Ilmu Komunikasi, 3(1), 75-84. https:// doi.org/10.14710/interaksi.3. $1.75-84$

Suharyo. 2018. "Nasib Bahasa Jawa dan Bahasa Indonesia dalam Pandangan dan Sikap Bahasa Generasi Muda Jawa". Nusa: Jurnal Ilmu Bahasa dan Sastra, 13(2), 244-255.

https:/ / doi.org/10.14710/nusa.13.2.2 44-255
Susanto, Tri Atmojo. 1991. "Kalatidha: Studi Tekstual dalam Rangka Pemahaman Maknanya". (Skripsi). Yogyakarta: Universitas Gadjah Mada. http:/ / digilib.fib.ugm.ac.id/files/view/ 6e444534d63909090987050d060de6d4.ph $\mathrm{p} \# / 0$

Tolo, Emilianus Yakob Sese. 2013. "Dari Otokrasi Ke Demokrasi: Menyibak Sejarah Dan Survivalitas "Demokrasi Ala Daerah Istimewa Yogyakarta"'". Humaniora, 25(3), 270-280.

Ulfa, Nurist Surayya. 2012. "Konsumsi Sebagai Penanda Kesejahteraan Dan Stratifikasi Sosial (Dalam Bingkai Pemikiran Jean Baudrillard)". Jurnal Forum, 40(1), 34-41-41.

Wardani, Laksmi Kusuma. 2012. "Pengaruh Pandangan Sosio-Kultural Sultan Hamengku Buwana IX Terhadap Eksistensi Keraton Yogyakarta". Jurnal Masyarakat dan Kebudayaan Politik, 25(1), 56-63.

http://journal.unair.ac.id/pengaruhpandangan-sosio-kultural-sultanhamengkubuwana-ix-terhadapeksistensi-keraton-yogyakarta-article4275-media-15-category-8.html 